\title{
THE INTERPRETATIVE EFFECT OF EUROPEAN LAW IN THE JUDGMENT OF THE CROATIAN CONSTITUTIONAL COURT No U-III-1410/2007
}

\begin{abstract}
Boris Stanić $\dot{c}^{*}$
Summary: On 13 February 2006, the Constitutional Court of Croatia issued a very important judgment in which it resolved a difficult situation created by divergent judgments of the Administrative Court of Croatia in which The Administrative Court ruled on decisions made by the Croatian Competition Agency. The Administrative Court's judgments diverged in the interpretation of the Stabilisation and Association Agreement between the Republic of Croatia and the European Community. In the ongoing pre-accession period it is of great importance to instruct the Croatian judiciary how and when the criteria and standards of the comparative law of the European Community should be applied. This is especially important in cases which involve the Croatian Constitutional Court, as its primary function is to preserve the division of powers in Croatia. According to the Administrative Disputes Act, ${ }^{1}$ an administrative dispute can be initiated against the decisions of administrative bodies ${ }^{2}$ against which appeals are not permitted, in other words before the Administrative Court. Given that the largest part of the European acquis communautaire relates to administrative law, the focus points of the application of European law in Croatia will be administrative legislation, administrative proceedings and administrative law in general.
\end{abstract}

\footnotetext{
"Boris Stanić, attorney at law, PhD candidate, Faculty of Law, University of Zagreb.The author wishes to thank Miljenko Giunio LLM, editor of the journal Pravo u Gospodarstvu, who previously published parts of this paper, Professor Siniša Rodin, Head of the Jean Monet Department for Public European Law at the University of Zagreb, and also his associates in the Department, for their helpful suggestions. Gratitude is also due to the Department for organising the annual 'Advanced Issues of European Law' seminar in Dubrovnik, where researchers can exchange opinions with respected international experts on European law.

${ }^{1}$ Official Gazette (OG) 53/91, 9/92 and 77/92. This was a regulation from the SFR Yugoslavia which was applied, with certain changes, in Croatia from 8 October 1991. At the moment this regulation was adopted, the one published in the Official Gazette of the SFR Yugoslavia 4/77 came into force. See Jakša Barbić, Građansko, Trgovačko, Radno i Upravno Pravo - Novine Nakon Preuzimanja Saveznih Propisa (Organizator, Zagreb 1992).

2 Ministries, ie the executive, are the most common bodies that decide in the second instance or, on the basis of law, issue decisions against which there is no opportunity to appeal. In this manner, the Administrative Court, as the judicial body, directly controls the decisions of the executive.
} 


\section{The relevant facts of the case}

The undertaking PZ Auto Ltd, headquartered in Velika Gorica, Zagrebačka bb (the licensed distributor for Volkswagen motor vehicles in Croatia) on 26 January 2001 cancelled further business co-operation ${ }^{3}$ regarding the distribution of Volkswagen personal motor vehicles with AMC Međimurje Ltd of Čakovec and Autohrvatska Pula Ltd of Pula. These two latter undertakings considered such conduct to be a violation of the Croatian Competition $\mathrm{Act}^{4}$ (hereinafter: the old CCA) and consequently initiated two separate proceedings before the Croatian Competition Agency (hereinafter: the Agency). The two proceedings were merged into one and the Agency finally reached a decision in which it established that PZ Auto Ltd had abused its monopolistic position on the market as licensed distributors of Volkswagen personal motor vehicles in Croatia. Consequently, the Agency ordered PZ Auto Ltd to continue business co-operation with all ${ }^{5}$ licensed distributors of Volkswagen vehicles in Croatia with which they had signed letters of intent for a period of one year. In addition, the Agency ordered PZ Auto Ltd to create, within a period of 30 days, a list of qualitative and objective criteria for remaining within the group of licensed distributors of Volkswagen vehicles and to deliver the list to the Agency and to everyone with whom it had established business co-operation on the basis of the letter of intent. PZ Auto Ltd was also ordered to sign a contract for a period of at least 5 years with all undertakings that had complied with the criteria.

Given that the Croatian competition law in force at the time did not contain any by-laws to regulate the distribution of motor vehicles, the Agency had, besides the old CCA,${ }^{6}$ through the principle of subsidiarity applied the methods, criteria and standards of the comparative law of

\footnotetext{
3 Business co-operation was based on a letter of intent which the undertaking PZ Auto Ltd of Zagreb, as an importer of Volkswagen vehicles, signed on 10 December 1999 with several undertakings in Croatia (including AMC Međimurje Ltd of Čakovec and Autohrvatska Pula Ltd of Pula) which thereby gained the status of licensed distributors. With this letter of intent, licensed Volkswagen distributors were obliged to ensure the façades of their facilities were in accordance with the directives given by the principal and instructions issued by the importer, ie PZ Auto Ltd. However, AMC Međimirje Ltd and Autohrvatska Pula Ltd were never, in two years of co-operation, given any instructions, directives or standards that referred to the appearance of retail or service facilities.

4 The area of competition entered the Croatian legal order in 1995. Precisely because of the need to join the European common market, Croatia started building a free-market system. In the last thirteen years, big steps have been taken in this field. The Croatian Competition Agency is the regulatory body that supervises, co-ordinates, approves, and also educates undertakings, and initiates proceedings concerning sanctions in certain cases. The activities of the Agency concerning the protection of competition can be divided into two time periods. The first refers to the time period from the foundation of the Agency until the signing of the SAA, and the second period refers to the period afterwards.

5 There were 27 distributors with whom PZ Auto Ltd was co-operating.

${ }_{6}$ At the time, the old Competition Act was in force (OG 48/95, 52/97, 89/98).
} 
the European Union on this subject. The authority to apply these rules existed, in the Agency's opinion, on the basis of Article 70/2 of the Stabilisation and Association Agreement between the European Community and its Member States and the Republic of Croatia (hereinafter: SAA) signed on 29 October $2001 .^{7}$ The provisions of Articles 40 and 70 of the SAA correspond to the provisions of Articles 27 and 35 of the Interim Agreement on trade and trade-related provisions between the European Community and the Republic of Croatia (hereinafter: Interim Agreement). The Interim Agreement was also signed on 29 October 2001 and was temporarily applied from 1 January 2002 (entering into force on 1 March 2002) until the entering into force of the SAA (1 February 2005). PZ Auto Ltd initiated an administrative dispute before the Administrative Court against the decisions of the Agency within the prescribed time limit. The Administrative Court refused the claim as non-grounded and affirmed the Agency's decision. ${ }^{8}$ Dissatisfied with the Administrative Court's judgment, PZ Auto Ltd filed an appeal against the judgment with the Croatian Constitutional Court.

\section{Applicable law}

Article 140 of the Constitution of the Republic of Croatia ${ }^{9}$ states that international agreements that are concluded and ratified in accordance with the Constitution and made public will be part of the Republic's internal legal order $^{10}$ and in terms of legal effect supersede the law. Their provisions may be changed or repealed only under conditions and in a way specified by them or in accordance with the general rules of international law.

The SAA is by its nature such an agreement. ${ }^{11}$ By signing the SAA, Croatia has taken the first important formal step in institutionalising its

\footnotetext{
7 OG - International Agreements, 14/01.

8 See Boris Stanić, ‘Europsko Pravo i Upravn Sud RH’ [2007] 3 Pravo u Gospodarstvu.

9 Constitution of the Republic of Croatia - consolidated version (OG 41/01, 55/01).

10 The same was provided for in Art 5 of the Courts Act in force at the time (OG 3/94, $100 / 96,131 / 97,129 / 00,101 / 03,17 / 04)$, which in subparagraph 2 stipulated that judges rule on the basis of international agreements that form part of the legal order of Croatia and that they apply other regulations that are enacted on the basis of the Constitution, international agreements or laws. The SAA is, as a ratified international agreement, a source of law. In terms of its legal effect, it supersedes laws, and is thus binding.

11 The SAA can be defined as an international agreement between Croatia and the Member States of the European Communities and the European Communities themselves. It was signed in 2001 and ratified in Croatia the same year. The other signatories required a longer period of ratification, which meant the SAA entered into force on 1 February 2005. In the opinion of Professor Siniša Rodin, this is an association agreement of a new generation of mixed agreements (mixed agreements are those that have to be ratified by both Member States and the European Community). See Siniša Rodin, 'Sporazum o Stabilizaciji i Pridruživanju u Pravnom Poretku Europske Zajednice i Republike Hrvatske' [2003] 3-4 Zbornik PFZ.
} 
relationship with the EU. This represents the start of the comprehensive work of implementing obligations that have been undertaken, as well as testing Croatia's ability to fulfil all the conditions necessary for full membership of the EU in all its three pillars. ${ }^{12}$

The process of harmonising the Croatian legal order with the European acquis communautaire has, in accordance with Article 69 of the SAA, become a permanent process. Each new Croatian regulation must be in accordance with European law, and existing regulations will be harmonised within a short period of time. In addition, it is expected that those who apply the regulations in all instances will interpret them in the spirit of European law. The new level of trade relations established with EU Member States by the SAA ${ }^{13}$ imposes the obligation of understanding European law and court practice.

As a consequence of signing the SAA and in order to implement it, Croatia adopted the new Competition $\mathrm{Act}^{14}$ (hereinafter: CCA) and various by-laws to regulate certain questions in a more detailed manner than the Act itself. The SAA contains provisions that regulate competition and that are very similar to the primary law and CCA. For example, Article 70 of the SAA states that the following are incompatible with the proper functioning of the SAA, in so far as they may affect trade between the Community and Croatia:

a) all agreements between undertakings, decisions by associations of undertakings and concerted practices between undertakings which have as their object or effect the prevention, restriction or distortion of competition;

b) abuse by one or more undertaking of a dominant position in the territories of the Community or of Croatia as a whole or in a substantial part thereof;

c) any State aid which distorts or threatens to distort competition by favouring certain undertakings or certain products.

These provisions have their source in Article 81 of the Treaty establishing the European Community and are also provided for in Article 9 of the CCA. It is important to emphasise that the SAA further on states that any practices contrary to these provisions will be assessed on the basis of criteria arising from the application of the competition rules appli-

\footnotetext{
12 On the metaphor of the three pillars of the EU see Eillen Denza, The Intergovernmental Pillars of the European Union (OUP, Oxford - New York 2002).

13 In the preamble of the agreement, the expectation is expressed that the SAA will create a new climate for economic relations between signatories, and above all for the development of trade and investment, factors crucial to economic restructuring and modernisation.

14 OG 122/03. See Siniša Petrović, 'Novo Hrvatsko Pravo Tržišnog Natjecanja' [2004] 4 Pravo u Gospodarstvu.
} 
cable in the Community. ${ }^{15}$ It also states that any practices contrary to these provisions will be assessed according to the criteria established by the Community on the basis of Articles 36 and 37 of the Treaty establishing the European Community and specific Community instruments adopted on this basis. These provisions are especially important for the following analysis of the judgments mentioned earlier.

\section{Proceedings}

Although it is in its nature a very complicated system and a very demanding subject, for the purpose of this paper it can, in general, be said that the CCA establishes proceedings in such a way that the Agency's decisions are considered final in administrative proceedings ${ }^{16}$ although an administrative dispute can be initiated against them.

On becoming independent, Croatia, through the adoption of existing federal laws, maintained the existing federal regulation of administrative proceedings and disputes. Although certain minor changes have been made, the regime has remained the same. The situation has remained like this for seventeen years since the adoption of the laws. In the meantime, the number of administrative proceedings has multiplied enormously and, in addition, the Administrative Court has been periodically encumbered with new cases mostly the result of political decisions which have been left to the administration to perform, such as cases regarding the acquisition of Croatian citizenship in the early 1990s, and cases concerning the payment of debts to pensioners in the late 1990s. In addition, many regulations stipulate that administrative bodies such as ministries, the government or government agencies or directorates, decide in the first instance and issue final decisions. The result of this whole situation is the relatively low level of efficiency of the Administrative Court. The average duration of proceedings before it is 3 years from the receipt of the initial application. The Administrative Court nowadays adjudicates in every possible field (citizenship, building licences, healthcare, social protection, registration of associations, renovation of homes destroyed during the war, cadastres, taxes, military service, etc). The panel of three judges that has to adjudicate in certain cases $^{17}$ is often, due to the long duration of proceedings, faced with the problem of passing judgment on

\footnotetext{
15 Especially Art 81, 82, 86 and 87 of the Treaty establishing the European Community, but also interpretative instruments adopted by Community institutions.

16 In Croatia, administrative proceedings are governed by the general rules on proceedings provided for in the General Administrative Proceedings Act (OG 51/91). This was a law of the former federal state which originated from 1956 but which was incorporated into the Croatian legal system at the time of the independence of Croatia on 8 October 1991.

17 See Željko Dupelj, 'Donošenje Odluka u Upravnom Sporu' [2003] 3 Pravo u Gospodarstvu.
} 
the basis of a regulation that is no longer in force. The system as it is demands too much from judges of the Court. In what have so far been unsuccessful attempts at judicial reform, the administrative judiciary has not been seriously looked at. Hence, there is no reason to expect that it will come under the spotlight any time soon.

There is also another important restriction affecting quality that Croatia has not remedied yet. This refers to the fact that the Administrative Court's sessions are not public, which means that proceedings take place without the participation of the parties. ${ }^{18}$ Such arrangements for court proceedings are not in accordance with the principles of European law in a broader sense. ${ }^{19}$ Such proceedings before the Administrative Court (provided for in Article 34 (1) of the Administrative Disputes Act) meant that Croatia had to make a reservation in respect of Article 6(1) of the European Convention on Human Rights (hereinafter: ECHR), the only reservation that Croatia had to make. It is obvious that Croatia, at the time of its accession to the Council of Europe, was not able to reform its administrative judiciary. However, given the obligations arising from accession to the EU, this question will have to be solved. ${ }^{20}$

In the field of competition, experts have constantly argued that a system in which a court lacking in specialisation and dealing with questions of competition in enormously long proceedings that are not in public is far from an ideal solution. ${ }^{21}$

In the first years in which the Administrative Court dealt with competition cases, there was no great flow of competition cases, as shown in Table $1 .{ }^{22}$

\footnotetext{
18 The law provides for the possibility of verbal argument if the complexity of the disputed administrative area (whether fact or law) or the need for a better and integral solution to the case so requires. It is up to the court to issue such a decision. However, this is merely a legal possibility that is never applied.

19 European law in a broader sense refers to the laws of the EU and the laws of the Council of Europe.

20 Other Central European countries are not immune to similar problems conditioned by the structure of their judiciaries and understanding of European legal subject matter; see Michal Bobek, 'A New Legal Order, or a Non-Existent One? Some (Early) Experiences in the Application of EU Law in Central Europe' (2006) in 2 Croatian Yearbook of European Law \& Policy 265 in which the author even raises the interesting question: Iura novit curia - Does it really?

21 See Siniša Petrović, 'Novo Hrvatsko Pravo Tržišnog Natjecanja' [2004] 4 Pravo u Gospodarstvu where proceedings for violations of competition whereby the Agency only initiates proceedings and a decision is issued by the Misdemeanours Court is also mentioned as a bad solution.

22 The table is taken from Jasminka Pecotić, 'Praksa Agencije za Zaštitu Tržišnog Natjecanja i Upravnog Suda RH u Pravu Tržišnog Natjecanja', materials for a specialised course on Competition Law and State Aid in the EU, Faculty of Law Rijeka - Tempus Project, Rijeka, 2005, and is based on data provided by the Agency.
} 
Table 1 Filed complaints before the Administrative Court in each reporting period 1997-2003

\begin{tabular}{|l|r|r|r|r|r|r|r|r|r|}
\hline & 1997 & 1998 & 1999 & 2000 & 2001 & 2002 & 2003 & total & structure \\
\hline total & 1 & 18 & 6 & 8 & 7 & 7 & 11 & 58 & $100 \%$ \\
\hline unsolved & 0 & 3 & 3 & 6 & 6 & 7 & 8 & 33 & $56.90 \%$ \\
finalised & 1 & 15 & 3 & 2 & 1 & 0 & 3 & 25 & $43.10 \%$ \\
\hline claim accepted & 0 & 2 & 0 & 1 & 0 & 0 & 1 & 4 & $16.00 \%$ \\
\hline claim refused & 1 & 11 & 2 & 1 & 1 & 0 & 1 & 17 & $68.00 \%$ \\
\hline claim rejected & 0 & 2 & 0 & 0 & 0 & 0 & 0 & 2 & $8.00 \%$ \\
\hline claim dropped & 0 & 0 & 1 & 0 & 0 & 0 & 1 & 2 & $8.00 \%$ \\
\hline
\end{tabular}

Source: Croatian Competition Agency, Economic Analysis Department

It is to be expected that the number of competition cases will eventually increase and bring about a change in the Administrative Court's approach.

The Administrative Court dealt with the case referred to above from 2003 until 2006 and reached a judgment (Us-4832/2003-6) on 9 November 2006 which was published in the Official Gazette (29/07) in March 2007. In the statement of grounds, the Court set forth the statements of the Applicant (PZ Auto Ltd):

In the statement of grounds of the contested judgment, with regard to the application of methods, criteria and standards of the comparative law of the European Union relating to the distribution of motor vehicles, the Applicant sees the misuse of laws and by-laws, contesting that Croatian competition law, as applied at the moment, does not contain any by-laws which regulate undertakings on the distribution of motor vehicles market. The applicant argues that the authority to apply such rules has been derived from Article 70 (2) of the SAA and Interim Agreement. However, Article 140 of the Croatian Constitution provides that international agreements in force constitute a part of the internal legal order. The SAA is not in force and therefore should not have been applied. The interim agreement, on the other hand, entered into force on 1 March 2002, while the letter of intent was cancelled on 26 March 2001, almost a year before the Interim Agreement entered into force and therefore, the body against which the application has been brought applied the Interim Agreement retroactively, which is not permitted. With regard to Article 35(2) of the Interim Agreement, which provides that any practices contrary to this provision will be assessed on the basis of criteria arising from the competition rules applicable in the Community, especially Articles 81, 82, 86 and 87 of the Treaty establishing the European Community and specific Community instruments adopted on this basis, the Applicant states that there are no official Croatian translations of such texts and nor are the interpretative instruments of international contracts published. The Applicant also points to the difference between the terms comparative law of the EU and EU law. 
The Administrative Court disagreed with the Applicant and determined as follows:

The body against whom the action was brought has not misused the law by applying the methods, criteria and standards of the comparative law of the European Union regarding the distribution of motor vehicles. The body affirms that in the absence of domestic by-laws to determine the methods, criteria and standards needed to assess the agreement, it applies the methods, criteria and standards of the comparative law of the EU relating to the distribution of motor vehicles. In this way, in the interest of the parties concerned, it shows a uniform approach in its assessment and highlights the methods and standards which it applies as criteria, thereby eliminating the possibility of using discretion in assessing the lawfulness of the proceedings, thus granting equality of all parties before it as a public authority. The Applicant ${ }^{23}$ did not apply the above-mentioned international acts and criteria solely as a legal rule, but is authorised to apply them on the basis of Articles 70 and 130 of the Stabilisation and Association Agreement between the European Community and its Member States and the Republic of Croatia.

The SAA regulates competition in Articles 40, 69 and 70 and it is provided for that any practices contrary to these provisions will be assessed on the basis of the criteria concerning competition rules applicable in the Community, especially Articles 81, 82, 86 and 87 of the Treaty establishing the European Community and specific Community instruments adopted on this basis. Articles 40 and 70 of the SAA correspond to Articles 27 and 35 of the Interim Agreement on trade and trade-related provisions between the European Community and the Republic of Croatia. The Interim Agreement was signed on 29 October 2001 and was temporarily applied from 1 January 2002. It entered into force on 1 March 2002 and will be applied until the entering into force of the SAA. ${ }^{24}$ The fact that the disputed contract which is to be assessed in this matter was signed before the entering into force of the Interim Agreement does not mean that aforementioned Agreement cannot be applied to it. This is because such international agreements have the purpose of eliminating from the market all arrangements that restrict or frustrate free competition.

Given the above, the Administrative Court refused the Applicant's (PZ Auto Ltd) claim as non-grounded. Thus, the undertaking had exhausted its regular legal remedies.

\footnotetext{
${ }^{23}$ This is obviously a composition error. The word 'Applicant' should be 'Defendant' or 'body against whom the case was brought'.

${ }^{24}$ Given that this judgment was issued at a panel session on 9 November 2006, the Administrative Court should have known that the SAA had entered into force on 1 February 2005 (OG - International Agreements 1/05).
} 
It is interesting that at approximately the same time, the Administrative Court in another three-judge panel reached a completely opposite decision. This was the judgment of the Administrative Court No Us-5438/3002-7 of 26 October 2006, published in Official Gazette No 16 in February 2007. Without examining the subject matter of the case, for the purpose of this paper it is necessary to highlight that part of the explanation of the judgment regarding the application of the criteria and standards of EU law by the Agency. The statement of grounds discusses that part of the claim that reflects the Applicant's position on the question. This part states:

The criteria and standards of EU law on the assessment of vertical agreements on which the accused body relies without mentioning the legal source are Article 81 of the Treaty establishing the European Community and acts of the Commission on the application of Article 81, which expressly regulate admissible and non-admissible terms of contracts. It should be borne in mind that Article 81 of the said agreement and the said acts represent regulations of the EU that regulate competition in the internal common market, ie the market inside the EU. The Applicant considers that the provision of Article 35 of the Interim Agreement, that is Article 70 of the Stabilisation and Association Agreement, can in no way be interpreted as an obligation (or authorisation) on the part of the authorities or other Croatian state bodies to directly apply the said provisions of the agreement and 'interpretative instruments adopted by the Community institutions', but can only be interpreted as the obligation of Croatia, as the signatory, to harmonise its legislation regarding competition with the legislation of the EU. The Applicant points out that the Competition Act does not regulate vertical agreements. By showing that the criteria contained in the provisions of the Treaty establishing the European Community and interpretative instruments adopted by the Community institutions' would be applicable in Croatia without the provisions and 'instruments' being published in an international agreement or incorporated and published in Croatian regulations, the Applicant demonstrates the direct application of foreign law in Croatia, which is against the provisions established in Article 4 of the Administrative Disputes Act and Article 19 of the Croatian Constitution.

The Administrative Court replied in an affirmative manner to the Applicant's claims in the second part of the explanation. It stated:

Regarding the application of the law, it must be stated that Article 140 of the Constitution states that international agreements that are concluded and ratified in accordance with the Constitution and made public shall be part of the Republic's internal legal order and 
shall in terms of legal effect supersede the law. Therefore, in this case the SAA and Interim Agreement could have been applied. However, the criteria, standards and interpretative instruments of the European Community upon which the body against whom the action was brought relies, are not included in the text of the agreement or incorporated or published in any other Croatian law or regulation, and therefore cannot be a source of law.

As a result of this situation the Court had sent out a confusing message. Comparatively, the situation appeared as follows:

\begin{tabular}{|c|c|}
\hline $\begin{array}{l}\text { Judgment of the } \\
\text { Administrative Court } \\
\text { No Us-5438/2003-7 of } \\
26 \text { October 2006 } \\
\text { (OG 16/07) }\end{array}$ & $\begin{array}{l}\text { Judgment of the Administrative Court } \\
\text { No Us-4832/2003-6 of } 9 \text { November } 2006 \\
\text { (OG 29/07) }\end{array}$ \\
\hline $\begin{array}{l}\text { The SAA and Interim } \\
\text { Agreement could have } \\
\text { been applied. However, } \\
\text { the criteria, standards } \\
\text { and interpretative in- } \\
\text { struments of the Euro- } \\
\text { pean Community upon } \\
\text { which the body against } \\
\text { whom the action had } \\
\text { been brought relies, } \\
\text { which are not included } \\
\text { in the text of the agree- } \\
\text { ment or incorporated or } \\
\text { published in any other } \\
\text { Croatian law or regula- } \\
\text { tion, cannot be a source } \\
\text { of law. }\end{array}$ & $\begin{array}{l}\text { The body against whom the action had been } \\
\text { brought had not misused the law by apply- } \\
\text { ing the methods, criteria and standards of the } \\
\text { comparative law of the EU. } \\
\text { In the absence of domestic by-laws to deter- } \\
\text { mine the methods, criteria and standards } \\
\text { needed to assess the agreement, the methods, } \\
\text { criteria and standards of the comparative law } \\
\text { of the EU are applied. } \\
\text { Consequently, in the interest of the parties, a } \\
\text { uniform approach in assessment is adopted } \\
\text { and the methods and standards applied as } \\
\text { criteria are clearly highlighted, thereby elimi- } \\
\text { nating any possibility of using discretion in the } \\
\text { assessment of the lawfulness of the proceed- } \\
\text { ings, thus ensuring the equality of all parties } \\
\text { before that body as a public authority. } \\
\text { The above-mentioned international acts and } \\
\text { criteria are not applied as sole legal rules, as } \\
\text { their application is authorised on the basis of } \\
\text { Articles } 70 \text { and } 130 \text { of the Stabilisation and } \\
\text { Association Agreement. }\end{array}$ \\
\hline
\end{tabular}

Such a situation was somewhat expected for those who were familiar with the Croatian judiciary. ${ }^{25}$ Nevertheless, it is almost incomprehensible

\footnotetext{
25 At a public discussion organised by the Jurist Club of the City of Zagreb under the title 'The Stabilisation and Accession Agreement with the EU and Croatian Legislation', held on 14 November 2002, Professor Siniša Rodin predicted situations like this by saying: ' 1 If the Agreement is directly applicable in the Croatian legal system, and it is, then our judges already need to understand Articles $81,82,86$ and 87 and the complete court practice and
} 
how a panel that stated the criteria, standards and interpretative instruments of the European Community could not be a source of law did not take into account the clear and unambiguous provision of Article 35 (3) of the CCA which provides:

In the assessment of the forms of prevention, restriction or distortion of competition which could affect trade between the Republic of Croatia and the European Community, the Agency in accordance with Article 70 of the Stabilisation and Association Agreement will apply in an appropriate way ... criteria which derive from the proper use of competition rules in the European Community. (emphasis added)

It is typical that PZ Auto Ltd, in its constitutional complaint that followed the judgment of the Administrative Court, relies on the dissenting position of the Administrative Court according to which criteria, standards and interpretative instruments of the European Community that are not included in the SAA or included or published in any other Croatian law or regulation cannot be a source of law.

The Constitutional Court, on the basis of Article 125 of the Constitution, decides on constitutional complaints against individual acts of state bodies, bodies of local or regional self-government, or legal persons with public authority, when they have violated human rights or fundamental freedoms or the right to local and regional self-government as guaranteed by the Constitution. This is further elaborated upon in Article 62 of the Constitutional Act on the Constitutional Court, ${ }^{26}$ which states that if another other legal remedy is provided against a violation of constitutional

acquis which have been developed on the basis of these articles. Whether that is really the case, you can judge for yourself; 2 If we have the obligation to adjust future legislation then a fortiori we must interpret our existing legislation in favour of the SAA and the whole acquis; 3 Our courts, especially regular courts, have undertaken the responsibility of applying the acquis in so far as we have accepted it, and in so far as we have to interpret our legislation. There is a certain jeopardy, and that is the possible disorientation of our judiciary, which is completely unprepared for such a venture.' In his paper 'Pridruživanje Hrvatske Europskoj Uniji: Preobrazba Pravnog Sustava' in Pridruživanje Hrvatske Europskoj Uniji - sv 1 - Ekonomski i Pravni Izazovi, (Institute for Public Finances \& Foundation Friedrich Ebert, Zagreb 2002) he gives another possibility: 'Under the interpretative principle favouring conventions, ie the interpretation of national legislation in accordance with international agreements, national courts of associated states can interpret the provisions of national law in accordance with the provisions of accession agreements, taking into consideration the present acquis communautaire, including the practice of the European Court. Such practice could eventually lead to the acceptance of the direct effect of directly applicable provisions of primary, and perhaps also secondary legislation, which derive from the accession agreement. The argument in favour of this approach is that associated states, by undertaking obligations from the agreement, intend to adjust national legal orders to the legal order of European law. The consequence of such intentions is also the obligation to interpret national law and accession agreements in accordance with the acquis communautaire.'

26 OG 49/02. 
rights, a constitutional complaint may be lodged only after this remedy has been exhausted. In matters in which an administrative dispute is provided for, as far as revision of civil or extra-litigation proceedings are concerned, a remedy is considered to be exhausted after a decision has been taken on that remedy. Article 68 additionally states that a panel composed of six judges will decide upon constitutional complaints, and that a panel comprising three judges will decide on constitutional complaints when procedural requirements for deciding upon them do not exist (eg lateness, no authorisation to lodge a constitutional complaint, inadmissibility etc). The panel can only decide unanimously and when all its members are present. If the panel does not reach a unanimous decision, or if the panel holds that the matter of the constitutional complaint is of broader significance, a Session of the Constitutional Court shall decide on the complaint.

In the case of the complaint of PZ Auto Ltd, a Session of the Constitutional Court decided. Since there were no dissenting opinions, it can be concluded that such a means of deciding was chosen because the case was of 'broader significance'.

At the session held on 13 February 2008, the Constitutional Court unanimously ${ }^{27}$ reached a decision in which it rejected the constitutional complaint of PZ Auto Ltd against Administrative Court judgment No Us4832/2003-6 of 9 September 2006 (OG 29/07), which referred to the Agency's decision Class: UP/I-030-02/2002-01/32, No 580-02-03-10-75 of 18 February 2003, as non-grounded. In the constitutional complaint, the Applicant alleged that the disputed Agency decision and Administrative Court judgment violated its constitutional rights as granted by Article 14(2) and Article 49(1) of the Constitution. ${ }^{28}$ Besides a claim based on wrongful and incomplete determination of the facts, the Applicant based its complaint on the misuse of law. ${ }^{29}$ The Applicant also stated that its practice had been wrongfully determined as a violation of Article 13 of the CCA as in force at the time. It stated that the mentioned provision

\footnotetext{
27 The Constitutional Court comprised Željko Potočnjak as presiding judge, and Marko Babić, Mario Kos, Davor Krapac, Ivan Matija, Jasna Omejec, Agata Račan, Aldo Radolović and Nevenka Černhorst as members of the panel.

28 Constitution of the Republic of Croatia (OG 41/01 - consolidated version and 55/01 - correction); Art 14 (2) states: 'All shall be equal before the law', Art 49 (1) states: 'Entrepreneurial and market freedom shall be the basis of the economic system of the Republic'.

29 It is the position of the Applicant that in proceedings before the Agency the SAA could not have been applied since it entered into force on 1 February 2005, and nor could the Interim Agreement apply since it entered into force on 1 March 2002. The Applicant points to the fact that both agreements entered into force after 26 February 2002 when it cancelled business co-operation with AMC Međimurje Ltd, and given that these agreements cannot be applied retroactively, such application by the Agency was against Art 90 (1) of the Constitution, which states: 'Before coming into force, laws shall be published in "Narodne Novin", the Republic's official gazette.'
} 
distinguished between monopolistic and dominant positions, while in the disputed judgment these two terms were mixed and thus, it was not clear which violation of the law had been committed. The Applicant also disputed the Court's finding that the relevant market refers to the Croatian market for Volkswagen vehicles, stating that the relevant market should be considered to be the market for all vehicles. ${ }^{30}$

\section{Interpretation}

Before analysing the Constitutional Court's decision, certain factors should be emphasised. The purpose of the SAA is to gradually make existing laws and future legislation compatible with the acquis communautaire, as provided for in Article 69 which stipulates:

1. The Parties recognize the importance of the approximation of Croatia's existing legislation to that of the Community. Croatia shall endeavour to ensure that its existing laws and future legislation will be gradually made compatible with the Community acquis.

2. This approximation will start on the date of signing of the Agreement, and will gradually extend to all the elements of the Community acquis referred to in this Agreement by the end of the period defined in article 5 of this Agreement. In particular, at an early stage, it will focus on fundamental elements of the Internal Market acquis as well as on other trade-related areas, on the basis of a programme to be agreed between the Commission of the European Communities and Croatia. Croatia will also define, in agreement with the Commission of the European Communities, the modalities for the monitoring of the implementation of approximation of legislation and law enforcement actions to be taken. (emphasis added)

It should be emphasised that the obligation of harmonising the law started with the date of the signing of the SAA and not on the day of its entering into force. This provision should also be placed within the context of the political goal of Croatia to become a full member of the EU. To this end, the Resolution of the Croatian Parliament of 18 December 2002 (OG 153/02) states that: 'the Republic of Croatia's full membership of the EU is a strategic national goal which the Croatian Parliament in its future activities will fully and constantly support.' The National Programme of the Republic of Croatia for Accession to the EU (OG 30/03) defines membership of the EU as being in the 'national interest'. Given that in the period between the signing of the SAA and its ratification Croatia gained the status of candidate country for full membership of the EU, it is obvi-

\footnotetext{
30 The Applicant states that its share in the market of all vehicles in Croatia in 2001 was $11.32 \%$, and in $20029.89 \%$, which shows that it had neither a monopoly nor a dominant position on the market at the time in question.
} 
ous that all sources of law, including the SAA, with the legal effect of an international agreement must be interpreted in the spirit of the Treaty establishing the European Community ${ }^{31}$ and the court precedents of the European Court of Justice seated in Luxembourg (hereinafter: ECJ).

The Constitutional Court, which is the highest court with powers to correct court practice in Croatia (although under the system of separation of powers it is not formally part of the judiciary, but a separate sui generis fourth power) has shown that it understands the core of European law. In decision U-III.1410/2007, the Constitutional Court, after giving a summary of first instance proceedings before the Agency and court proceedings before the Administrative Court, emphasised that Article 70 (1) of the SAA and Article 36(1) of the Interim Agreement stipulate, among other things, that in so far as it may affect trade between the Community and Croatia, abuse by one or more undertakings of a dominant position in the territories of the Community or of Croatia as a whole or in a substantial part thereof is considered incompatible with the proper application of the SAA and Interim Agreement. The Constitutional Court here emphasised that conduct against the provisions of the SAA and Interim Agreement must be interpreted on the basis of the criteria derived from the application of the competition rules of the European Community, especially Articles 81 and 82 of the Treaty establishing the European Community and the interpretative instruments adopted by the institutions of the European Community (Article 70 (2) of the SAA and Article 35 (2) of the Interim Agreement). In a long-awaited judgment, ${ }^{32}$ the Constitutional Court stated the following:

Following the previously said, in cases where distortion of competition is being assessed, Croatian bodies that deal with competition are authorised and obliged to apply criteria that derive from the

\footnotetext{
31 Art 10 (previously Art 5) of the Treaty establishing the European Community contains the obligation of loyalty and the principle of fidelity, the aims of which are positive co-operation in fulfilling obligations arising out of the Treaty and support for the Community. It prohibits any measure which could jeopardise the attainment of the objectives of the Treaty. See Simonetta Gerli, Compendio di Diritto dell'unione Europea (Diritto Comunitario); Aspetti Giuridici e Istituzionali (Esselibri, Napoli 2003). A similar provision should have been contained in the European Constitution. See Olivier Duhamel, Le Constitution Européenne (Armand Colin, Paris 2005). In this respect, the judgment was very important in the case Factortame I (Case-213/89 $R v$ Secretary of State for Transport, ex parte Factortame [1990] ECR I-2433 [1990] 3 WLR 852) where it was determined that from the perspective of the Community, loyalty to the Treaties obliges Member States to loyally fulfil their treaty obligations, to which should be added the coherent and unlimited fulfilment of community law, especially when creating their national legal orders. See Stephen Weatherill, Cases \& Materials on EU Law (Oxford University Press, Oxford - New York 2003).

32 This was a long-awaited judgment that many experts had predicted. In this respect I would like to single out Academician Jakša Barbić and Professors Siniša Rodin and Tamara Čapeta from the Department for Public European Law of the Faculty of Law at the University of Zagreb.
} 
application of the competition rules of the European Community and interpretative instruments adopted by the institutions of the European Community. In this respect the SAA and Interim Agreement oblige Croatian bodies in charge of protection of competition, that when resolving cases, not only to apply Croatian competition law, but also take into consideration the rules of competition law of the European Community. (emphasis added)

The Constitutional Court considered that the provisions of the SAA and Interim Agreement could have been applied in the proceedings before the Agency and Administrative Court in a general manner, provided that the conduct of the undertaking was being assessed at a time when these international agreements were in force. The Constitutional Court raised the question of application of the criteria, standards and interpretative instruments of the European Community, which means the SAA and Interim Agreement. With regard to the Applicant's claim that the criteria, standards and interpretative instruments of the European Community could not be applied due to the fact that they had not been included or published in any Croatian law or regulation and thus were not a source of law, the Constitutional Court responded that such a statement had no grounds as the aforementioned criteria, standards and instruments were not applied as a primary source of law but only as a subsidiary means of interpretation. The Constitutional Court took the stand that Article 70(2) of the SAA and Article 35(2) of the Interim Agreement had to be interpreted in the context of Croatia's obligation to harmonise its legislation, including that part that regulates competition, with the European acquis. When applying such harmonised legislation, the state bodies of Croatia are obliged to apply it as it would be applied in the EU, ie with regard to the purpose and spirit of the provisions with which the legislation is harmonised. This derives from the provision of Article 70(2) of the SAA which states:

Any practices contrary to this Article shall be assessed on the basis of criteria arising from the application of the competition rules applicable in the Community, in particular from Articles 81, 82, 86 and 87 of the Treaty establishing the European Community and interpretative instruments adopted by the Community institutions.

In this respect, when assessing whether practices of a certain undertaking are in accordance with competition rules, not only are Croatian competition rules relevant, but due regard must also be given to all European Community competition rules. The Constitutional Court concluded:

The law of the European Community is not formally introduced into the Croatian legal order by virtue of the provisions of the SAA as an international agreement, but it is provided for that Croatian competition rules should be applied in the light of the rules, criteria and principles of competition law. 
In the Constitutional Court's opinion, what had occurred in the administrative proceedings before the Agency and the application of the criteria, standards and interpretative instruments of the European Community was the filling of a legal gap in a way that conformed to the spirit of national law and that was not contrary to the explicit solutions of the CCA in force at the time.

At the end of its judgment, the Constitutional Court concluded:

- that competition rules are by their nature public law due to their purpose of protecting the public good (free competition), and due to the fact that they serve the exercising of entrepreneurial and market freedoms in a way that prevents, among other things, undertakings from violating the entrepreneurial and market freedoms of other undertakings and consumers, and

- that by the mere restriction of the conduct of an undertaking that distorts competition, the protection of free competition can be provided for.

\section{What now?}

With its decision of 18 February 2008, the Constitutional Court has shown Croatian courts what course they should take in this pre-accession period. We must be aware that a long time still has to pass until teleological interpretation of legal rules suppresses the widely accepted linguistic interpretation. However, the Constitutional Court has, by virtue of its authority, taken a huge step in this direction. It was to be expected that the first interpretative doubts would occur precisely in the fields that have entered for the first time into our legal system through the process of accession to the EU. The matter of competition is the best example of this. This case showed all the weaknesses of the existing system in its provision of remedies against the Agency's decision in the form of initiating an administrative dispute before the Administrative Court. In the future, the regular courts will face further disputes that require the interpretation of national law in accordance with the purpose and spirit of European law.

For now, a situation in which two panels of the same court decide on subject matter of the highest importance in a completely opposite manner may testify to the degree of independence of judges, but more probably speaks of a certain lack of knowledge. ${ }^{33}$

\footnotetext{
33 Professor Zvonimir Lauc in his paper 'Osposobljenost Sudaca za Pošteno Suđenje i Razuman Rok' in Arsen Bačić and others, Pravo na Pošteno Suđenje i Razuman Rok - Pravo Azila (Organizator, Zagreb 2003) claims that the independence of judges is manifested through the issuance of judgments, which means through the interpretation of regulations. This in turn means that judges must be great interpreters of regulations, but also connoisseurs of the circumstances to which regulations refer. In a concrete case, the court panel in Us$5438 / 2003-7$ of 26 October 2006 (OG 16/2007) failed in this respect.
} 
There are a few brave judges in Croatia who have no fear about stating their opinions and are prepared to argue for them. Our judicial system has become so bureaucratic that, unlike American (and now European) students who quote judgments of well-known judges (and opinions of attorney generals), our students are perhaps familiar only with those judges who judge war crimes or organised crime cases, or with those whose judgments the public makes fun of or condemns. To make things worse, court spokesmen have recently been introduced as the interface between the public and judges, which has the purpose of reducing public interest in trials. However, no matter how much one tries to reduce the interest of legal experts in court practice, such experts have a right and obligation to analyse court practice, comment on it and point to the discrepancies and misuse of law that they notice. As long as there is a judge capable of saying:

... the criteria, standards and interpretative instruments of the European Community upon which the body against whom the action was brought relies, are not included in the text of the agreement or incorporated or published in any other Croatian law or regulation, and therefore cannot be a source of law

Croatia has a serious problem ${ }^{34}$ and we should not close our eyes to it. It is inappropriate ${ }^{35}$ to comment here whether Croatia should become a member state of the EU or not, but euroscepticism cannot become an alibi for ignorance and misinterpretation of the law. The question of the effectiveness of the judiciary is one of the fundamental problems of all countries in transition. ${ }^{36}$ Transition does not only mean changes in the

\footnotetext{
34 At a public discussion organised by the Jurist Club of the City of Zagreb under the title 'The Stabilisation and Accession Agreement with the EU and Croatian Legislation' held on 14 November 2002, Academician Jakša Barbić unambiguously concluded: 'We already have some regulations that are very close to European standards. It only takes a little to adjust them to newer things, but unfortunately they are applied in a Balkan manner from the judiciary downwards. This is a Croatian problem. And when we speak of the legal side of the problem, I think this will be the hardest. What does this mean? In all segments of society, an effort should be made to lift the level of expert deliberation and conduct, and not only in the matter of legislation. I will now state a heretical idea that I have, and that I wrote in one of our high profile academic journals. There is no real political will for this in Croatia. There is at the declarative level, but not at the real one, because if there was real political will, steps would have been taken, ones to which experts have been alert for a long time, moves that are really not hard to take and which in comparison to the benefits they bring, the costs are a bargain. However, this has not happened. I am not talking about left-wing or right-wing parties. I am talking about the entire Croatian political arena.'

35 The geopolitical position of Croatia and the moment of its international recognition played a crucial role in its deciding in favour of the EU, and full membership will also occur in the context of global events. Still, it would be better if the Croatian political elite was not so obsessed with the date of gaining full membership, but rather focused on the education of all those who will have a decisive role in a future European Croatia. This of course refers to the judiciary as well.

36 See Michal Bobek, 'A New Legal Order, or a Non-Existent One? Some (Early) Experiences in the Application of EU Law in Central Europe' (2006) 2 Croatian Yearbook of Euro-
} 
economic system, but also very painful political, social and especially legal reforms. Given the subject matter of this paper, we should restrict ourselves to legal reforms. These refer to:

a) legislative reform,

b) judicial reform (and administrative, as well ${ }^{37}$ ), and

c) the training of all who participate in these systems. ${ }^{38}$

Some legal experts mention the need to achieve a certain degree of legal culture in all Central European countries in transition. ${ }^{39}$ However, it should also be noted that there are other opinions which point to the fact that the world today is different from fifty, or even fifteen years ago, and that the definitions that have formed the basis of the opinions of (continental) jurists for centuries are questionable. The notions of state and sovereignty, private and international law, human rights, civil society, court precedence, and criminal responsibility ${ }^{40}$ are today ready to be redefined, and judges are the first that will have to take their share of responsibility. Hopefully, the availability of court judgments in the Official Gazette and on the internet will bring about greater responsibility and raise the profile of new generations of judges that will make interpretations by which they will be remembered, because law today is not engraved in stone. Naturally, Croatian judges are not the first to face this responsibility. For example, a few years ago in Poland, at a time when it was a candidate for full membership of the EU, a question arose concerning the application of the aquis communautaire. The Polish Constitutional Court resolved doubts with an interesting standpoint:

Of course, EU law is not legally binding in Poland. However, the Constitutional Court would like to emphasise the provisions of Articles 68 and 69 [Poland Accession Agreement] ... With this, Poland is obliged to put 'its best efforts into ensuring that future legislation

pean Law \& Policy 265 and Daniela Nováčková, Základy Európskeho Práva a Vnútorný Trh Európskej Únie (Eurounion, Bratislava 2004).

37 This especially refers to the redefining of the role and radical reform of the Administrative Court.

38 This refers to members of Parliament, the executive power, judiciary and public administration.

39 See Siniša Rodin, 'Discourse and Authority in European and Post-Communist Legal Culture' (2005) 1 Croatian Yearbook of European Law \& Policy 1; Zdenék Kühn, 'The Authoritarian Legal Culture at Work: the Passivity of Parties and the Interpretational Statements of Supreme Courts' (2006) 2 Croatian Yearbook of European Law \& Policy 19; Tamara Čapeta, 'Interpretativni Učinak Europskog Prava u članstvu i prije članstva u EU' [2006] 5 Zbornik Pravnog fakulteta u Zagrebu.

40 For example, a student that twenty years ago in an exam on criminal law stated that a legal entity could be held criminally liable, would for sure not have passed the exam. Today, the concept of the criminal liability of a legal entity is accepted and thus, Croatia has included it in its legal system. See The Criminal Liability of Legal Entities Act (OG 151/03). 
is in accordance with that of the Community' ... The Constitutional Court considers that the obligation to ensure the compatibility of legislation (which is primarily the obligation of Parliament and the Government) also results in the obligation to interpret existing legislation in such a way as to ensure the highest possible degree of compatibility. ${ }^{41}$

The fact that Croatia has finally met one such decision does not give us the right to think that our work is done. It is still our obligation to closely monitor how the law is interpreted, and to point to those judgments that do not have all the qualities that court judgments need to have in this pre-accession period.

41 Taken from Tamara Čapeta, 'Interpretativni Učinak Europskog Prava u članstvu i prije članstva u EU' [2006] 5 Zbornik Pravnog fakulteta u Zagrebu in which the author refers to the original presented by Professor Z Kühn in his paper 'Application of European Law in Central European Candidate Countries' (2003) 28 ELRev 551. 